\title{
Karyotype Analysis of Lallemantia Fisch. \& C.A.Mey. Species Grown in Turkey: A Detailed Karyotype Asymmetry Study
}

\author{
Irfan $\mathrm{EMRE}^{1 *}$, Osman GEDIK ${ }^{2}$, Murat KÜRSAT $^{3}$, Yasar KIRAN $^{4}$ \\ ${ }^{1}$ Department of Basic Education, Faculty of Education, Firat University, Elazig, 23119, Turkey \\ ${ }^{2}$ Faculty of Agriculture, Department of Field Crops, Kahramanmaras Sutcu Imam University, Kahramanmaras, \\ 460640, Turkey \\ ${ }^{3}$ Faculty of Science and Arts, Department of Biology, Bitlis Eren University, Bitlis, 13000, Turkey \\ ${ }^{4}$ Faculty of Science and Arts, Department of Biology, Firat University, Elazig, 23119, Turkey \\ (ORCID: 0000-0003-0591-3397) (ORCID: 0000-0002-4816-3154) \\ (ORCID: 0000-0002-0861-4213) (ORCID: 0000-0002-3225-2080)
}

\begin{abstract}
The study aimed to karyologically analyse three species [(Lallemantia peltata (L.) Fisch. \& Mey., Lallemantia iberica (Bieb.) Fisch. \& Mey. and Lallemantia canescens (L.) Fisch. \& Mey.)] from Lallemantia Fisch. \& C.A.Mey. (Lamiaceae) grown in Turkey. Also, it was calculated various karyotype asymmetry and $\mathrm{S} / \mathrm{A}_{\mathrm{I}}, \mathrm{CV}_{\mathrm{CL}}$ and $\mathrm{M}_{\mathrm{C}}$ values in this study. Seed samples were given natural habitats and Feulgen staining method was used. The study showed that the chromosome numbers of Lallemantia species are $2 \mathrm{n}=14$ and that they have median (m) and submedian ( $\mathrm{sm}$ ) centromeric chromosomes. The study also demonstrated karyotype analysis and asymmetry values and suggested that three species of Lallemantia genus were 2A based on Stebbins classifications. Furthermore, the study showed Pearson correlation using karyotype asymmetry values and a scatter diagram was formed using $\mathrm{A}_{1}$ and $\mathrm{A}_{2}$. The results obtained from the study were compared with the results of karyotype analysis performed by different literatures and it was concluded that there may be differences according to locality.
\end{abstract}

Keywords: Chromosome, Lallemantia, Karyotype Asymmetry, Karyotype Formula, Stebbins Classification.

\section{Türkiye'de Yetişen Lallemantia Fisch. \& C.A.Mey. Türlerinin Karyotip Analizleri: Detaylı Karyotip Asimetri Çalışması}

\begin{abstract}
Öz
Bu çalışma Türkiye'de yetişen Lallemantia Fisch. \& C.A.Mey. cinsine ait üç türün [Lallemantia peltata (L.) Fisch. \& Mey., Lallemantia iberica (Bieb.) Fisch. \& Mey. and Lallemantia canescens (L.) Fisch. \& Mey.)] karyolojik analizinin yapılmasını amaçlamıştır. Ayrıca, bu araştırmada çeşitli karyotip asimetrisi ve / $\mathrm{A}_{\mathrm{I}}, \mathrm{CV}_{\mathrm{CL}}$ and $\mathrm{M}_{\mathrm{C}}$ değerleri de hesaplanmıştır. Tohum örnekleri doğal habitatlarından toplanmış ve Feulgen boyama metodu kullanılmıştır. Bu çalışma, Lallemantia türlerinin kromozom sayılarının 2n=14 olduğunu ve median ve submedian sentromer kromozomlara sahip olduklarını bulmuştur. Ve ayrıca, bu çalışma Lallemantia cinsine ait üç türün Stebbbins sınıflandırmasına göre 2A grubunda olduğunu ileri sürmüş ve karyotip analizi ve asimetri değerlerini göstermiştir. Bundan başka, bu çalışma karyotip asimetri değerlerini kullanarak Pearson korelasyonunu ve $\mathrm{A}_{1}$ and $\mathrm{A}_{2}$ 'yi kullanarak saçılım grafiğini göstermiştir. Çalışmadan elde edilen sonuçlar, farklı literatürler tarafindan yapılan karyotip analizlerinin sonuçlarıyla karşılaştırılmış ve lokailtelere göre farklılıklar olabileceği sonucuna ulaşılmıştır.
\end{abstract}

Anahtar Kelimeler: Lallemnantia, Karyotip Asimetrisi, Karyotip Formulü, Stebbins Sinıflandırması.

\section{Introduction}

Lamiaceae, represented by about 236 genera and 7000 taxa, is distributed throughout the world but especially in the Mediterranean. The endemism ratio of the family is 45\% [1-3]. In the Flora of Turkey,

*Corresponding author: irfanemre@gmail.com

Received: 20.08.2020, Accepted: 15.10.2020 
the family has 45 genera and 735 taxa [1]. The subtribe Nepetinae comprises 12 genera and 350 taxa and is distributed in Eurasia and North America [4].

Lallemantia, a small genus from the Nepetinae, includes five species and is found in Europe, southwest Asia and the Himalayas [5]. The species from Lallemantia are annual or biennial plants that are used as food or for medicinal purposes [6]. In Turkey, Lallemantia (Ajdarbaş1) is represented by three species: L. canescens (topajbaş1), L. peltata (kalkanbaş1) and L. iberica (ajdarbaş1) [7]. L. iberica, known as Dragon's head, is cultivated for the high oil content of its seeds [8]. L. canescens has blue flowers and an attractive smell and is used ornamentally in gardens while L. peltata with its volatile oils is used as a medicinal plant [1,9]. L. iberica and L. peltata are annual herbs whilst $L$. canescens is perennial [10].

Chromosome studies are used in plant systematics to contribute to taxonomical knowledge. They can also be used for geographical and taxonomical comparisons [10]. Karyological studies showed that Lallemantia species have $2 \mathrm{n}=2 \mathrm{x}=14$ chromosomes [11,12]. Similarly, Ozcan et al. [10] found that three Lallemantia species grown in Turkey at different localities to those in this study had $2 \mathrm{n}=14$ chromosomes. This study aimed to karyologically analyse three species of Lallemantia (L. peltata, $L$. iberica and $L$. canescens) grown in Turkey and to compare the results with various studies from different localities.

\section{Material and Method}

\subsection{Materials}

The samples were gathered from natural habitats in Turkey in 2012-2013 and stored at the Bitlis Eren University Herbarium (BEUH) (Table 1, Figure 1).

Table 1. Localities of Lallemantia studied

\begin{tabular}{|c|c|}
\hline Locality & Voucher number \\
\hline B9, Bitlis, Bitlis Eren University, Rahva campus, north slopes, 2600 m, 12.08 .2012 & Kursat 6002 \\
\hline B7, Elazı ğ; Baskil, Bolucuk village, 1480 m, 12.09.2013. & Kursat 6005 \\
\hline B9, Bitlis, Nemrut mountain, steppes, 2290 m, 12.08.2012. & Kursat 6001 \\
\hline
\end{tabular}

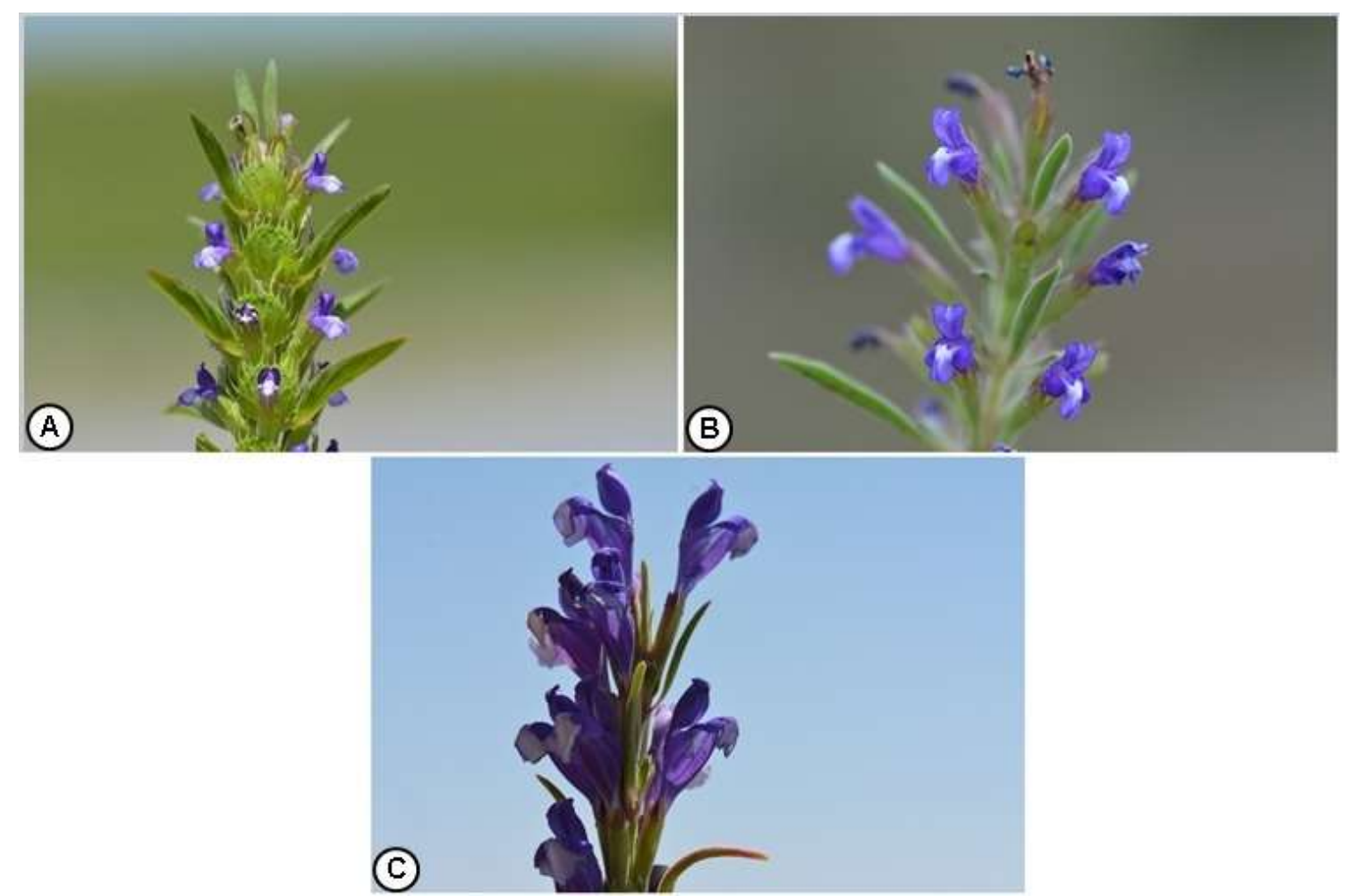

Figure 1. The Photographs of Lallemantia studied (A: L. peltata; B: L. iberica; C: L. canescens) 


\subsection{Method}

The seeds were vegetated at $25{ }^{\circ} \mathrm{C}$ and the tips of the roots were treated with aqueous $\alpha$ monobromonaftalin for $12 \mathrm{~h}$ at $+4^{\circ} \mathrm{C}$ in a refrigerator and fixed with glacial acetic acid-absolute ethanol (1:3) for at least $24 \mathrm{~h}$ at $4{ }^{\circ} \mathrm{C}$. Then, hyrolysed process was done $\left(5 \mathrm{~min} ., 1 \mathrm{~N} \mathrm{HCl}, 60^{\circ} \mathrm{C}\right)$ and rinsed in tap water for 3-5 min. Lastly, Feulgen was used for staining about 1h [13]. Photographs of metaphase chromosomes were taken from Olympus BX51 microscope and Olympus Camedia C-4000 digital camera.

\subsubsection{Karyotype analysis}

In this study, we measured, ploidy level, karyotype formula, total karyotype length (TKL), ranges of chromosome length, somatic chromosome number (2n), relative lengths (RL), arm ratios (AR), centromeric indices (CI), and Stebbins classification [14]. Classifications of centromeric positions and karyotype formulae were determined based on the methods of Levan et al. [15].

\subsubsection{Karyotype asymmetry}

This study used percent of symmetry index (SI\%), index of karyotypic asymmetry (AsK\%), total form percentage (TF\%), value of relative chromatin (VRC), resemblance between chromosomes (Rec. index), symmetric indices (Syi index), dispersion index (DI) and difference of relative length (DRL) as the karyotype asymmetry [16-21]. The intra-chromosomal asymmetry index (A1) and interchromosomal asymmetry index (A2) were measured using the method of Romero Zarco [22] and the dispersion diagram was prepared using $A_{1}$ and $A_{2}$ (fig.4). Furthermore, this study also showed the S/A $A_{I}$ (karyotype symmetry/asymmetry index), $\mathrm{CV}_{\mathrm{CL}}$ (coefficient of variation of chromosome length; interchromosomal asymmetry) and $\mathrm{M}_{\mathrm{CA}}$ (mean centromeric asymmetry; intrachromosomal asymmetry) [23,24].

\subsubsection{Statistical analysis}

Pearson correlation was calculated based on karyotype asymmetry results using SPPS 21.0 (IBM Corporation, USA). 0.01 and 0.05 levels were used to compare the correlations.

\section{Results and Discussion}

The results of karyotype analysis [somatic chromosome number (2n), ploidy level, karyotype formula, ranges of chromosome length, TKL, $\mathrm{A}_{1}, \mathrm{~A}_{2}$ indices and Stebbins classification] are given in Table 2 while RL, AR, CI] and Stebbins classification [14] are given in Table 3. Also, the findings of karyotype asymmetry [TF, SI\%, AsK\%, VRC, Syi index, Rec. index, DI, DRL, S/A $\mathrm{A}_{\mathrm{I}}, \mathrm{CV}_{\mathrm{CL}}$, and $\mathrm{M}_{\mathrm{CA}}, \mathrm{A} 1, \mathrm{~A} 2$ are given in Table 4.

Table 2. Poidy level. Somatic chromosome number (2n), karyotype formula, ranges of chromosome length, total karyotype length (TKL) and Stebbins classification for the studied Lallemantia species

\begin{tabular}{lcccccc}
\hline Taxa & 2n & $\begin{array}{c}\text { Ploidy } \\
\text { level }\end{array}$ & $\begin{array}{c}\text { Karyotype } \\
\text { formula }\end{array}$ & $\begin{array}{c}\text { Chromosome } \\
\text { length range } \\
(\boldsymbol{\mu m})\end{array}$ & $\begin{array}{c}\text { TKL } \\
(\boldsymbol{\mu m})\end{array}$ & $\begin{array}{c}\text { Stebbins } \\
\text { classification }\end{array}$ \\
\hline L. peltata & 14 & $2 \mathrm{x}$ & $1 \mathrm{~m}+6 \mathrm{sm}$ & $1.82-2.87$ & 15.84 & $2 \mathrm{~A}$ \\
L. iberica & 14 & $2 \mathrm{x}$ & $3 \mathrm{~m}+4 \mathrm{sm}$ & $1.46-2.43$ & 13.07 & $2 \mathrm{~A}$ \\
L. canescens & 14 & $2 \mathrm{x}$ & $2 \mathrm{~m}+5 \mathrm{sm}$ & $1.56-2.18$ & 12.88 & $2 \mathrm{~A}$ \\
\hline
\end{tabular}


Table 3. Karyomorphological parameters of Lallemantia species

\begin{tabular}{|c|c|c|c|c|c|}
\hline & Pair no & RL & $\mathrm{AR}$ & CI & Type \\
\hline \multirow{7}{*}{ L. peltata } & I & 18.12 & 2.18 & 31.44 & $\mathrm{sm}$ \\
\hline & II & 15.72 & 2.26 & 30.59 & $\mathrm{sm}$ \\
\hline & III & 14.59 & 1.26 & 44.06 & $\mathrm{~m}$ \\
\hline & IV & 14.17 & 2.03 & 32.97 & $\mathrm{sm}$ \\
\hline & V & 13.32 & 1.98 & 33.48 & $\mathrm{sm}$ \\
\hline & VI & 12.59 & 2.12 & 32.04 & sm \\
\hline & VII & 11.51 & 2.23 & 30.88 & $\mathrm{sm}$ \\
\hline \multirow{7}{*}{ L. canescens } & $\mathrm{I}$ & 16.99 & 2.03 & 32.90 & $\mathrm{sm}$ \\
\hline & II & 15.30 & 1.64 & 37.87 & $\mathrm{~m}$ \\
\hline & III & 15.89 & 2.01 & 33.17 & $\mathrm{sm}$ \\
\hline & IV & 13.81 & 2.06 & 32.66 & $\mathrm{sm}$ \\
\hline & V & 13.06 & 1.46 & 40.60 & $\mathrm{~m}$ \\
\hline & VI & 12.79 & 2.04 & 32.86 & $\mathrm{sm}$ \\
\hline & VII & 12.15 & 2.13 & 31.84 & sm \\
\hline \multirow{7}{*}{ L. iberica } & I & 18.60 & 2.07 & 32.49 & $\mathrm{sm}$ \\
\hline & II & 15.83 & 1.56 & 38.95 & $\mathrm{~m}$ \\
\hline & III & 15.32 & 2.04 & 32.78 & sm \\
\hline & IV & 13.95 & 1.98 & 33.55 & $\mathrm{sm}$ \\
\hline & $\mathrm{V}$ & 12.89 & 1.44 & 40.82 & $\mathrm{~m}$ \\
\hline & VI & 12.21 & 2.02 & 33.05 & sm \\
\hline & VII & 11.18 & 1.53 & 39.39 & $\mathrm{~m}$ \\
\hline
\end{tabular}

Table 4. Karyotype Assymetry of Lallemantia species

\begin{tabular}{lllllllllllllc}
\hline Species & TF\% & SI\% & As.K\% & VRC & Syi & Rec. & DI & DRL & S/A & CV $_{\text {CL }}$ & M $_{\text {CA }}$ & A $_{\mathbf{1}}$ & $\mathbf{A}_{\mathbf{2}}$ \\
\hline L. peltata & 32,82 & 62,71 & 67,11 & 0,31 & 48,99 & 88,8 & 2,39 & 3,36 & 1,85 & 7,24 & 32,70 & 0.48 & 0.15 \\
\hline L. iberica & 35,63 & 60,08 & 64,39 & 0,26 & 55,0 & 85 & 3,08 & 3,7 & 1,57 & 8,83 & 28,76 & 0.43 & 0.17 \\
\hline L. canescens & 34,67 & 68,88 & 65,21 & 0,26 & 52,94 & 93 & 1,94 & 2,21 & 1,71 & 5,43 & 30,9 & 0.46 & 0.12 \\
\hline
\end{tabular}

\section{Lallemantia peltata (L.) Fisch. \& Mey.}

It has $2 \mathrm{n}=14$ chromosome and includes one median (m) and six submedian (sm) chromosomes (Table 2, Figures 2A-3A). Lengths of the chromosomes ranged from $1.82 \mu \mathrm{m}$ to $2.87 \mu \mathrm{m}$ and TKL was $15.84 \mu \mathrm{m}$. The ratio of the longest to shortest chromosome was 1.5:1. This study found that AR values were between 1.26 and 2.26, CI values were between 30.59 and 44.06 and RL values were between $11.51 \%$ and $18.12 \%$ (Tables 2-3).

\section{Lallemantia iberica (Bieb.) Fisch. \& Mey.}

It has $2 \mathrm{n}=14$ chromosome and includes three median $(\mathrm{m})$ and four submedian (sm) chromosomes (Table 2; Figures 2B-3B). Lengths of the chromosomes ranged from $1.46 \mu \mathrm{m}$ to $2.43 \mu \mathrm{m}$ and TKL was $13.07 \mu \mathrm{m}$. The ratio of the longest to shortest chromosome was 1.6:1. (Tables 2-3). This study found that AR values were between 1.44 and 2.07, CI values were between 32.78 and 40.82 and RL values were between $11.18 \%$ and $18.60 \%$ (Tables $2-3$ ).

\section{Lallemantia canescens (L.) Fisch. \& Mey.}

It has $2 \mathrm{n}=14$ chromosome and includes two median (m) and five submedian (sm) chromosomes (Table 2, Figures 2C-3C). Lengths of the chromosomes ranged from $1.56 \mu \mathrm{m}$ to $2.18 \mu \mathrm{m}$ and TKL was $12.88 \mu \mathrm{m}$. The ratio of the longest to shortest chromosome was 1.3:1 (Tables 2-3). This study found that AR values were between 1.46 and 2.13, CI values were between 31.84 and 40.60 and RL values were between $12.15 \%$ and $16.99 \%$ (Tables 2-3). 

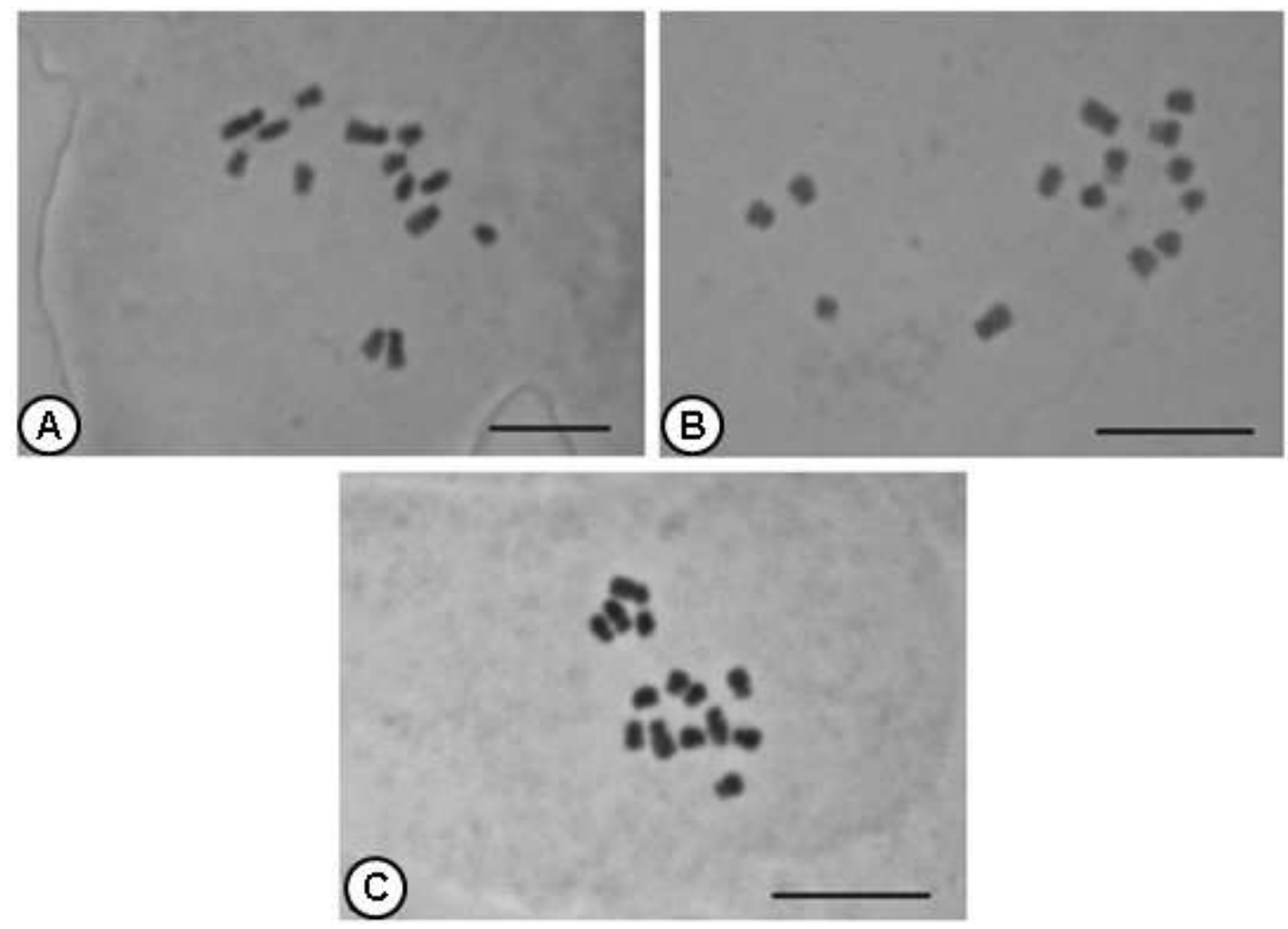

Figures 2. Metaphase chromosomes of Lallemantia species. A: Lallemantia peltata, B: Lallemantia iberica, Lallemantia canescens

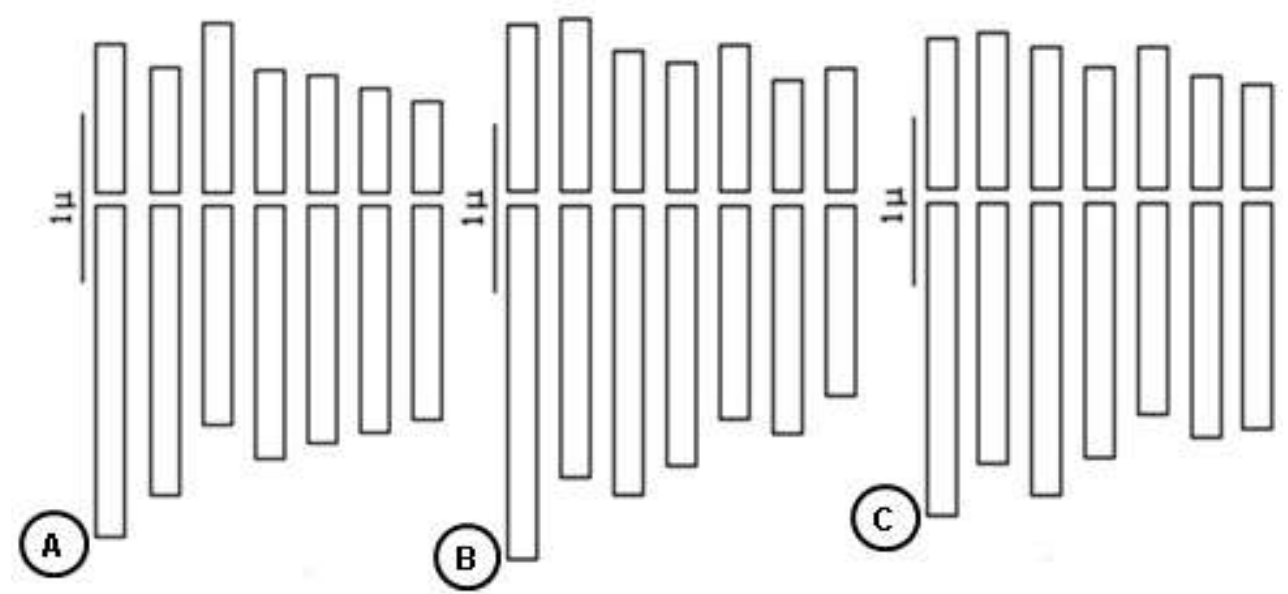

Figures 3. Haploid ideograms of Lallemantia studied. A: Lallemantia peltata; B: Lallemantia iberica.; C: Lallemantia canescens

Current data demonstrated that the karyotype formula of $L$. peltata is $1 \mathrm{~m}+6 \mathrm{sm}$, the karyotype formula of $L$. iberia is $3 \mathrm{~m}+4 \mathrm{sm}$ and the karyotype formula of $L$. canescens is $2 \mathrm{~m}+5 \mathrm{sm}$. However, Ozcan et al. [10] findings regarding the karyotype formula conflicted with the present study. They found that three Lallemantia species had a karyotype formula of $6 m+1 \mathrm{sm}$ [10]. Also, Dolatyari and Kamrani [25] showed that various Lallemantia species including L. iberica, L. canescens and L. peltata have $2 \mathrm{n}=2 \mathrm{x}=14$ chromosomes. They also found that accessions of L. peltata $\left(1 \mathrm{M}+4 \mathrm{~m}+2 \mathrm{sm}^{1 \mathrm{st}} ; 5 \mathrm{~m}+2 \mathrm{sm}\right.$; $1 \mathrm{M}+3 \mathrm{~m}+3 \mathrm{sm}), L$. iberica $(1 \mathrm{M}+3 \mathrm{~m}+3 \mathrm{sm} ; 1 \mathrm{M}+4 \mathrm{~m}+2 \mathrm{sm}+2 \mathrm{Bs})$ and $L$. canescens $(4 \mathrm{~m}+3 \mathrm{sm} ; 5 \mathrm{~m}+2 \mathrm{sm})$ have karyotype formulae that differ from the present study and they observed two B-chromosomes in one accession of L. iberica [25]. This difference among Lallemantia accessions may be due to geography. A karyotype study done by Martin et al. [26] supported the theory that the karyotypes of species gathered from various areas might change. They explained that this resulted from infraspecific 
and infrageneric variations such as climatological, geographical and ecological [26]. Reda et al. [27] also indicated that the chromosome structure and karyotype of the accessions might change because of significant adaptations.

On the other hand, the current study determined that the TF\% varied from $32.82 \%$ to $35.63 \%$; SI varied from 60.08 to 68.88 ; As.K\% varied from 64.39 to 67.11 ; VRC varied from 0.26 to 0.31 ; Syi varied from 48.99 to 55 ; Rec. index varied from 85 to 93 ; DI varied from 1.94 to 3.08; DRL varied from 2.21 to $3.7 ; \mathrm{S} / \mathrm{A}_{\mathrm{I}}$ varied from 1.57 to $1.85 ; \mathrm{CV}_{\mathrm{CL}}$ varied from 5.43 to $8.83, \mathrm{M}_{\mathrm{CA}}$ varied from 28.96 to 32.70; A1 varied from 0.43 to 0.48 ; and $\mathrm{A} 2$ varied from 0.12 to 0.17 . (Table 4 ). This study demonstrated that Lallemantia species studied possess symmetric karyotypes $\left(1.0<\mathrm{S} / \mathrm{AI} \leq 2.0 ;[22]\right.$ according to $\mathrm{S} / \mathrm{A}_{\mathrm{I}}$. Also, the present study determined that Lallemantia species are 2A based on Stebbins classification. However, Ozcan et al. [10] demonstrated that L. canescens and L. iberica are 2A whereas L. peltata are 2B according to the Stebbins classification. In addition, the scatter diagram based on A1 and A2 showed that Lallemantia species exhibited close localisation (Figure 4). Furthermore, the Pearson correlation calculated using karyotype asymmetry values and correlation is significant at 0.01 and 0.05 (Table 5).

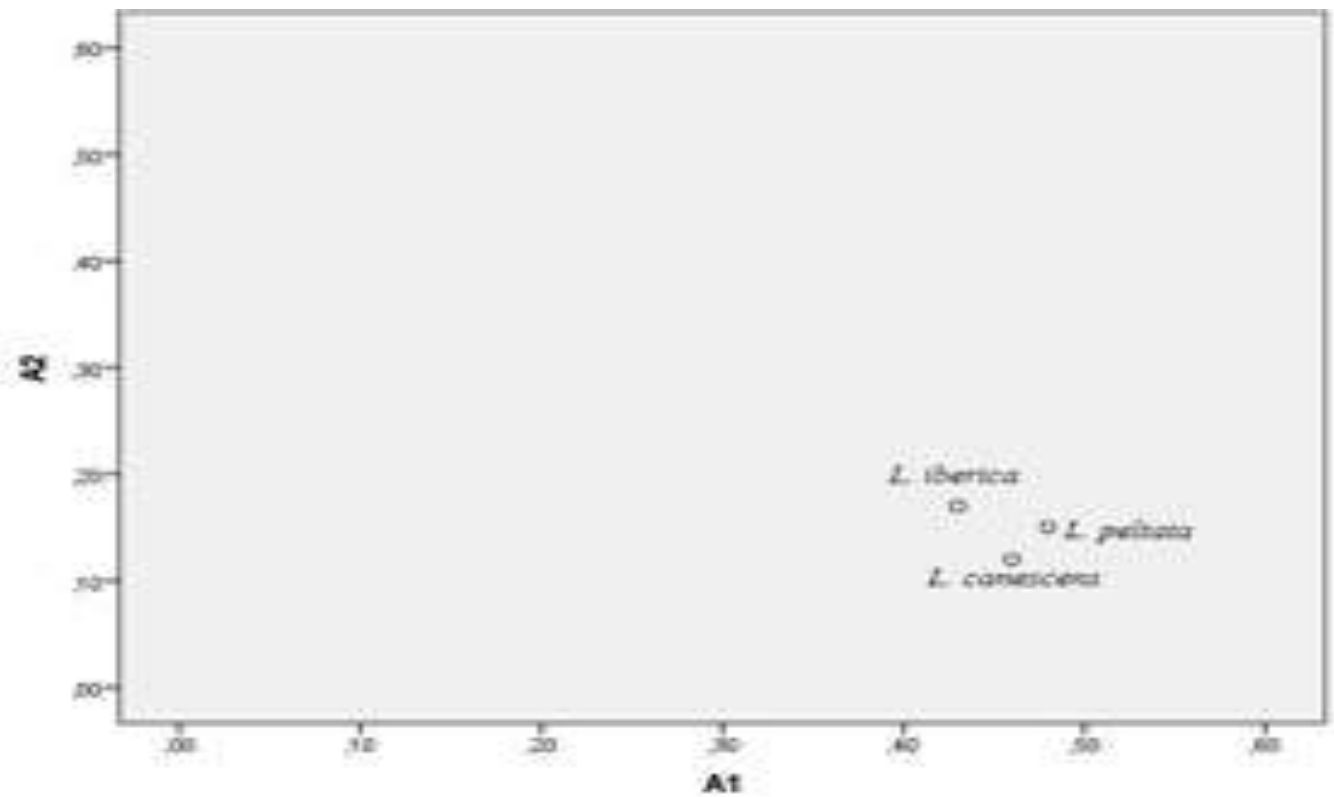

Figure 4. Scatter diagram based on $A_{1}$ and $A_{2}$

Table 5. Pearson correlation for karyotype asymmetry

\begin{tabular}{|c|c|c|c|c|c|c|c|c|c|c|c|c|c|}
\hline & TF\% & SI\% & As.K\% & VRC & Syi & Rec. & DI & DRL & S/A & $\mathrm{CV}_{\mathrm{CL}}$ & $\mathrm{M}_{\mathrm{CA}}$ & $\mathrm{A}_{1}$ & $\mathrm{~A}_{2}$ \\
\hline $\mathrm{TF} \%$ & 1 & ,540 & ,919 & ,762 & $1,000 * *$ & ,363 & ,955 & ,992 & ,984 & ,990 & 991 & ,998* & ,998* \\
\hline SI\% & ,540 & 1 & ,829 & ,957 & ,541 & ,980 & ,766 & ,433 & ,683 & ,655 & ,646 & ,595 & ,595 \\
\hline As.K\% & ,919 & ,829 & 1 & ,956 & ,919 & ,702 & ,995 & ,863 & ,975 & ,966 & ,962 & ,943 & ,943 \\
\hline VRC & ,762 & ,957 & ,956 & 1 &, 763 &, 880 & ,920 & 677 &, 866 &, 847 &, 840 & ,803 &, 803 \\
\hline Syi & $1,00 * *$ & ,541 & ,919 & ,763 & 1 & ,364 & ,955 & ,992 & ,984 & ,990 & ,992 & ,998* & ,998* \\
\hline Rec. & ,363 & ,980 &, 702 & ,880 & ,364 & 1 & ,624 & ,246 &, 525 &, 493 & ,482 & ,424 &, 424 \\
\hline DI & ,955 & ,766 & ,995 & ,920 & ,955 & ,624 & 1 & ,911 & ,993 & ,987 & ,985 & ,972 & ,972 \\
\hline DRL & ,992 & ,433 & ,863 & ,677 & ,992 & ,246 & ,911 & 1 & ,954 & ,965 & ,968 & ,982 & ,982 \\
\hline S/A & ,984 & ,683 & 975 & ,866 & ,984 & ,525 & ,993 & ,954 & 1 & ,999* & ,999* & ,993 & ,993 \\
\hline $\mathrm{CV}_{\mathrm{CL}}$ & ,990 & ,655 & ,966 & ,847 & ,990 & ,493 & ,987 & ,965 & ,999* & 1 & $1,00 * *$ & ,997* & ,997* \\
\hline $\mathrm{M}_{\mathrm{CA}}$ & ,991 & ,646 & ,962 & ,840 & ,992 & ,482 & ,985 & ,968 & ,999* & $1,00 * *$ & 1 & ,998* & ,998* \\
\hline $\mathrm{A}_{1}$ & ,998* & ,595 & ,943 & ,803 & ,998* & ,424 & ,972 & ,982 & ,993 & ,997* & ,998* & 1 & $1,00^{*}$ \\
\hline $\mathrm{A}_{2}$ & ,998* &, 595 & ,943 & ,803 & ,998* & ,424 & ,972 & ,982 & ,993 & ,997* & ,998* & $1,00 * *$ & 1 \\
\hline
\end{tabular}




\section{Conclusion}

This study demonstrated that the Lallemantia species grown in Turkey have $2 n=2 x=14$ chromosomes. Also, the present study found that $L$. peltata has $1 \mathrm{~m}+6 \mathrm{sm}$ karyotype formula, $L$. iberia has $3 \mathrm{~m}+4 \mathrm{sm}$ karyotype formula and $L$. canescens has $2 \mathrm{~m}+5 \mathrm{sm}$ karyotype formula. The research also showed that three Lallemantia species are 2A based on Stebbins' classification. Furthermore, correlation was found based on karyotype asymmetry values and present results supported the contention that karyotypes display differences depending on locality.

\section{Authors' Contributions}

All authors contributed equally to the study

\section{Statement of Conflicts of Interest}

There is no conflict of interest between the authors.

\section{Statement of Research and Publication Ethics}

The author declares that this study complies with Research and Publication Ethics.

\section{References}

[1] Alan S., Ozkan Y., Tuncer O. 2010. Taxonomical, Morphological and Anatomical Studies on Lallemantia Fisch. \& Mey J. Fac. Pharm. Ankara, 39 (1): 17-34.

[2] Khoury M., Stien D., Eparvier V., Ouaini N., El Beyrouthy M. 2016. Report on the Medicinal Use of Eleven Lamiaceae Species in Lebanon and Rationalization of Their Antimicrobial Potential By Examination of the Chemical Composition and Antimicrobial Activity of Their Essential Oils. Evidence-Based Complementary and Alternative Medicine, 1-18.

[3] Celep F., Dirmenci T. 2017. Systematic and Biogeographic Overview of Lamiaceae in Turkey. Nat. Volatiles \& Essent. Oils, 4 (4): 14-27.

[4] Dinc M., Pinar N.M., Dogu S., Yildirimli S. 2009. Micromorphological Studies of Lallemantia (Lamiaceae) Species Growing in Turkey. Acta Biologica Cracoviensia Series Botanica, 51 (1): 45-54.

[5] Kamrani A., Riahi M. 2018. Using Molecular Data to Test the Monophyly of Lallemantia in the Subtribe Nepetinae (Mentheae, Lamiaceae). Plant Biosystems, 152 (4): 857-862.

[6] Sheidai M., Koohdar F., Poode Z.M. 2018. Molecular Phylogeny of Lallemantia L. (Lamiaceae): Incongruence Between Phylogenetic Trees and the Occurrence of HGT. Genetika, 50 (3): 907918.

[7] Dirmenci T. 2012. Guner A., Aslan S., Ekim T., Vural M., Babac M.T. (edlr.). Vascular Plants List of Turkey: 555. Nezahat Gokyigit Botany Garden and Flora Research Org. Publish: Istanbul.

[8] Shafiee S., Motlagh A.M., Minaee S., Haidarbigi K. 2009. Moisture Dependent Physical Properties of Dragon's Head Seeds (Lallemantia iberica). Agricultural Engineering International: the CIGR Ejournal, XI: 1-10.

[9] Sheidai M., Poode Z.M., Koohdar F., Talebi S.M. 2018. Infra-Specific Morphological, Anatomical and Genetic Variations in Lallemantia peltata (L.) Fisch. \& C. A. Mey. (Lamiaceae). Acta Biologica Sibirica, 4 (3): 85-93.

[10] Ozcan T., Gezer E., Martin E., Dirmenci T., Altinordu F. 2014. Karyotype Analyses on The Genus Lallemantia Fisch. \& C.A.Mey. (Lamiaceae) from Turkey. Cytologia, 79 (4): 553-559.

[11] Astanova S.B. 1984. Chromosome Numbers in the Species of the Families Alliaceae, Asteraceae, Caryophyllaceae, Ebenaceae, Linaceae, Oleaceae, Lamiaceae from Tadjikistan. Bot Zhurn SSSR, 69: $1563-1564$.

[12] Daviña J.R., Honf A.I. 2018. IAPT Chromosome Data 28. Taxon, 67 (6): 1235-1245.

[13] Elci S. 1982. Observations and Reserarch Methods in Cytogenetics. Frrat University Press Elazig.

[14] Stebbins G.L. 1971. Chromosomal Evolution in Higher Plants. Edward Arnold, London. 
[15] Levan A., Fredga K., Sandberg A.A. 1964. Nomenclature for Centromeric Position on Chromosomes. Hereditas, 52 (2): 201-220.

[16] Huziwara Y. 1962. Karyotype Analysis in Some Genera of Compositeae. VIII Further Studies on the Chromosome of Aster. Americ. J. Bot., 49: 116-119.

[17] Arano H. 1963. Cytological Studies in Subfamily Carduoideae (Compositae) of Japan. IX. The Karyotype Analysis and Phylogenic Considerations on Pertya and Ainsliaea. Bot Mag (Tokyo), 76: 32-39.

[18] Greilhuber J., Speta F. 1976. C-Banded Karyotypes in the Scilla hohenackeri group, S. persica and Puschkinia (Liliaceae). Plant Syst Evol., 126 (2): 149-188.

[19] Lavania U.C., Srivastava S. 1992. A Simple Parameter of Dispersion Index That Serves As An Adjunct to Karyotype Asymmetry. J. Biosci., 17 (2): 179-182.

[20] Paszko B. 2006. A Critical Review and A New Proposal of Karyotype Asymmetry Indices. Plant Syst Evol., 258 (1-2): 39-48.

[21] Hesamzadeh H.S.M, Ziaei N.M. 2010. Cytotaxonomy of Some Onobrychis (Fabaceae) Species and Populations in Iran. Caryologia, 63 (1): 18-31.

[22] Romero-Zarco C. 1986. A New Method for Estimating Karyotype Asymmetry. Taxon, 35 (3): 526-530.

[23] Peruzzi L., Eroglu H.E. 2013. Karyotype Asymmetry: Again, How to Measure and What to Measure? Comparative Cytogenetics, 7: 1-9.

[24] Eroglu H.E. 2015. Which Chromosomes Are Subtelocentric or Acrocentric? A new Karyotype Symmetry/Asymmetry Index. Caryologia, 68: 239-245.

[25] Dolatyari A., Kamrani A. 2015. Chromosome Number and Morphology of Some Accessions of Four Lallemantia Fisch. \& C.A. Mey. (Lamiaceae) species from Iran. Wulfenia, 22: 127-135.

[26] Martin E., Akan H., Ekici M., Aytac Z. 2010. Karyology of Ten Turkish Trigonella L. (Leguminosae) Species From Section Cylindricae Boiss. Turk. J. Bot., 34: 485-494.

[27] Reda H.A., El-Shanshoury S.A.R., Safaa A.R., El-Sherif D.E.A.A. 2014. Karyotype Dynamic Variation Among Accessions of Lathyrus sativus L. From Different Geographic All Regions. Egypt J Exp Biol (Bot.), 10 (2): 107-113. 